\title{
The Effect of Wine Tourism Experiences on Wine Brands
}

\author{
Ricardo Correia $^{1, *}$, Raquel Meneses ${ }^{2}$, Sílvia David ${ }^{3}$ \\ ${ }^{1}$ Polytechnic Institute of Braganca, Portugal \\ ${ }^{2}$ Faculty of Economics, University of Porto, Portugal \\ ${ }^{3}$ Polytechnic Institute of Coimbra, Portugal
}

Copyright $\mathrm{O} 2016$ by authors, all rights reserved. Authors agree that this article remains permanently open access under the terms of the Creative Commons Attribution License 4.0 International License

\begin{abstract}
Wine tourism takes on a clear hedonic dimension, being especially prone to the design of experiences. The characteristics of wine tourism make this product quite compatible with the rural areas and with an evident capacity of sustainable development. Most of the studies that characterize the wine tourism experiences have a clear focus on the demand side. This paper aims at obtaining a greater insight into the leverage of the wine brands through positive experiences associated with wine tourism. Sustained on the Grounded Theory, a deep analysis of the perception that the cellars/farms have about the effect of their touristic offer on their wine brands was carried out. While there is no use of concrete measures on the supply-side, we found that there is the conviction of a reciprocal leverage effect between wine tourism experiences and wine brands. Despite the exploratory nature of this paper we conclude that wine experiences and brand value and awareness reinforce which other in an interactive and dynamic way.
\end{abstract}

Keywords Wine Tourism, Experiences, Wine Producers, Wine Brands, Marketing

\section{Introduction}

Most studies on wine tourism focus on the perspective of the consumer, analysing the visits to wine cellars and wine areas, events, as well as wine clubs [7]. However, the marketing of the wine cellars and the wine sale strategies are a key issue in wine tourism [11], insofar as a correct and deep perception of wine tourism companies of the market and consumer is a key factor for the development of the sector.

Despite the creation of experiences for the consumer being the target of a growing attention of the brands, it is still necessary to understand and improve their management [15]. Several companies have created thematic environments that allow consumers to experience and immerse themselves in the world of the brand. In an increasingly digital era which has transformed all forms of interpersonal contact, the place where, and the way the wine tourist experiences and interacts with the wine brands is fundamental.
There are several studies in the field of the consumer experience management that focus on consumer's intrinsic motivations. But the extrinsic motivations resulting from the stimulus offered by the wine producers, is a rarely considered subject. The main attempted contribution of this study is the enlargement of the experiential marketing analysis applied to the wine tourism from the supply perspective. In other words, the aim is to understand the perception the wine cellars/farms have of the effect of their wine experiences on theirs wine brands.

To achieve these objectives, the article is organized as follows: In section 2 a review of the literature based on two fundamental pillars (wine tourism and the experience itself) is presented. In the following section we present the research question and the basis of the analysis model. In section 4 the adoption of a qualitative methodology is justified, based on the Grounded Theory, which guides this research. Then the analysis of the cases will be presented. The article ends with a set of conclusions, limitations and suggestions for further research.

\section{Experiential Marketing in Wine Tourism}

The essence of tourism in today's world is based on the development and delivery of travel experiences, understand and experience the nature of different destinations and the way people in these places live, work and enjoy life [25]. For Ritchie et al.[25], the evolution of tourism in the post-World War II, changed from the supply of tourism products to the supply of tourism experiences. This change represents a global transformation that Pine and Gilmore[23] define as "Experience economy".

Wine tourism is a segment of the tourism activity, which allows publicizing the potential of a wine region, and even may be responsible for creating a sustainable competitive advantage to strengthen tourist services, such as accommodation, catering, the dissemination of cultural heritage and landscape. This can be achieved through visits to vineyards, wine cellars, museums, participation in festivals and other cultural events [9] and also using the 
educational component and the link to art [7]. This tourism, which is mainly located outside the metropolitan areas, assumes an important role in the sustainable development of rural regions [24] and more specifically of the wine regions, with the incorporation of the image of tourist destinations and a marketing opportunity that enhances the social, economic and cultural value of the wine region [7]. Wine is a kind of tourist attraction for the wine cellars [13] and must affirm itself as the main product of tourist destinations that has this feature [2,21]. Despite this, most of the owners of the estates still do not possess any training in the area of tourism, which would allow them to offer a quality product and understand the way this industry (so different from the wine industry) works. Wine production is the result of arduous tasks, which are performed hidden inside the farms or estates. Tourism requires sensitivity, openness and understanding of the visitors' motivations and needs [8].

We should also mention that the wine tourism activity is an extension of the quite complex relationship, among wine cellars, wine regions and visitors-consumers [6]. This means, according to these authors, that the "engagement" between people connected to wine tourism (wine cellars, wine regions and consumers) seems to be a logical path to a better familiarity with the product. The very nature of wine tourism involves the indulgence of the senses in the wine product and their immediate aesthetic surroundings and therefore an experiential vision of the wine tourism consumption seems justified $[6,10]$.

In practice, it has been noted that the strategy of the wine regions producers changed the emphasis on wine production and related activities to more aesthetic and experiential aspects [31]. There is an inflection in the theme based on the landscapes of vineyards, carefully cultivated within wine regions with intact natural landscape, to a strong emphasis on natural, cultural and rural recreation sceneries of the wine regions [32].

For Brown and Getz[5], the needs and motivations of the wine tourists are linked to more holistic leisure and vacation activities and not necessarily to aspects of wine consumption by itself. This holistic experience occurs in the context of what is known as winescape [17,22]. That is, the rural landscape where agriculture is practised, the landscape of vineyards and the wine cellars [17]. Winescape makes it possible for tourists to engage in hedonic experiences, in aesthetically pleasing atmospheres, of both physical and natural origins. That is, a memorable experience that does not happen only inside the wine cellar. The "total experience" is a unique combination of atmosphere, environment, regional culture and wine [6].

Another factor for the consumer experience is the interface of the service provided [30], and should be worthy of careful planning. It focuses on the links between the technology involved, either on the farm or at the website, or for the management of information and to the human component.

Finally, in the strategy of any organisation the quality, variety and innovation of the service provided in each farm should be considered. It must be referred that the employees who contact with the consumer are a source of information that should not be missed [33]. Indeed, a company oriented to the consumer experience considers the innovation and creativity of its employees as critical intellectual capital to the organization [27].

\section{Research Question and Analysis Model}

The main contribution intended to achieve with this study is the enlargement of the experiential marketing analysis applied to wine tourism from the supply side. Specifically it is intended to obtain a greater knowledge about the leverage of the wine brands through providing positive touristic experiences associated with wine. As such, the research question is:

What is the perception that the wine cellars/vineyards have about the effect of wine tourism experience on their wine brands?

The answer to this question was sought with the aid of an analysis model (Figure 1) developed through the literature review. The model aims to translate the process of reciprocal influence between the experience offered and the valorisation of the producer brands, serving also as an instrument to support empirical research, in that each of its dimensions is an important guidance on the information to be collected and analysed (Table 1).

When we look to experience dimension, we can divide the motivation for visiting a farm in intrinsic motivations to the consumer (consumer personal reasons, such as travelling to the region for work purposes), but also from extrinsic motivations, which result from the stimulus offered by the owners of the farms. The stimulus provided by the farms focus, as shown by diverse authors (for example, [17,1,32]), in the atmosphere of the farm (surrounding landscape, demarcated region, infrastructure, for example, the access to the farm), the region's culture, enogastronomy, the care about the details of the farm decoration (in both the outdoor and indoor spaces, the harmonious combination of spaces, etc.) in the interface of the service provided [30], (for example, the technology involved, either on the farm or at the site level, or for the management of information and the human component), on the quality, variety and innovation of the service provided in each farm, the price strategy (including promotions), in the dissemination strategies (public relations, activities carried out in the farm) $[4,19,26,29]$, and networks created to the potentiation of the wine tourism in the region (partnerships, coopetition and associations) $[3,14,18]$. 


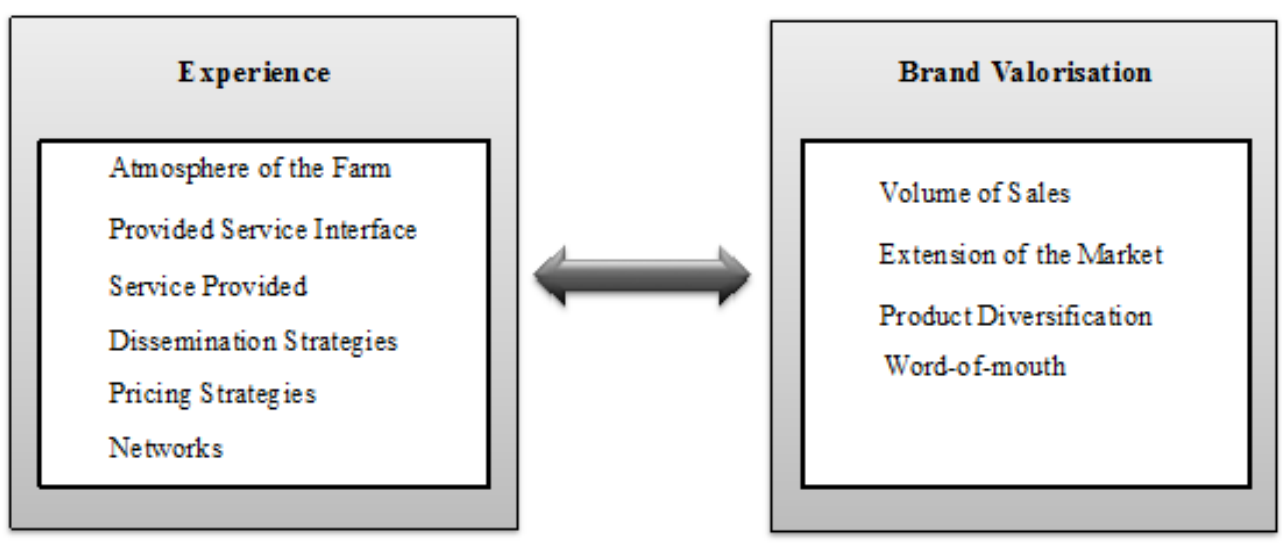

Figure 1. Analysis Model

Table 1. Analysis Dimensions

\begin{tabular}{llll}
\hline Dimensions & & Sub-dimensions \\
\hline & Experience & A1 & Atmosphere of the Farm \\
& A2 & Provided Service Interface \\
& A3 & Service Provided \\
& A4 & Dissem ination Strategies \\
& A5 & Pricing Strategies \\
& A6 & Networks \\
& & \\
& & \\
& B1 & Volume of Sales \\
& B2 & Ex tension of the Market \\
& B3 & Product Diversification \\
& B4 & Word-of-mouth \\
& & \\
\hline
\end{tabular}

Table 2. Conducted Interviews ${ }^{1}$

\begin{tabular}{|c|c|c|c|}
\hline NAME & COMPANY & POSITION & $\begin{array}{c}\text { INTERVIEW } \\
\text { DATE }\end{array}$ \\
\hline Paulo Mesquita & Casa de Sezim & Manager & $15^{\mathrm{ml}}$ January 2012 \\
\hline Catarina Pimentel & Quinta da Pacheca & Manager & $28^{\text {th }}$ January 2012 \\
\hline Isabel Morais & Sogrape & $\begin{array}{l}\text { Wine Tourism } \\
\text { Manager }\end{array}$ & $24^{\text {th }}$ April 2012 \\
\hline João Carvalho & Dão Sul & $\begin{array}{l}\text { Wine Tourism } \\
\text { Manager }\end{array}$ & $26^{\text {th }}$ April 2012 \\
\hline Sara Matos & Quinta Luís Pato & $\begin{array}{l}\text { Wine Tourism } \\
\text { Manager }\end{array}$ & $26^{\text {th }}$ April 2012 \\
\hline João Soares & $\begin{array}{l}\text { Herdade da } \\
\text { Malhadinha Nova }\end{array}$ & Manager & $30^{\text {th }}$ April 2012 \\
\hline $\begin{array}{l}\text { Francisco Guedes } \\
\text { Almeida }\end{array}$ & Quinta da Aveleda & Manager & $23^{\text {rd }}$ April 2012 \\
\hline
\end{tabular}

\footnotetext{
${ }^{1}$ The name of the sample companies is published since all respondents authorized the use of the responses in the publication.
} 
Thus, it is important to infer whether the experiences offered potentiate or not the valorisation of the brand. This effect is captured in the model by the volume of wine sales, the extension of market, product diversification and word-of-mouth

If the model is applied, the more and better experiences are provided to the consumers, the more highly valued the wine brands will be. This process will be interactive. If the supply of experiences to the consumer enhances the valorisation of the brands, this valorisation allows a positive return to the producer, encouraging him to generate more experiences relating to the wine product, thus creating an upward or positive continuous cycle [16].

\section{Methodology}

The work carried out is of exploratory nature and was accomplished through a methodology based on the grounded theory, as suggested by Glaser and Strauss[12], starting from a theoretical basis provided by the existing literature [28], and using the study of several cases, new categories were obtained. To achieve the objective set semi-structured interviews were carried out to 7 wine companies from North to South of Portugal, which, all in all, includes 14 distinct spaces of wine tourism (Table 2).

Company's selection respected a threefold aim: have a sample with national scale coverage, capture some of the best examples in wine tourism and achieve theoretical saturation as defined by Glaser and Strauss[12].

The data collected in this study results from the use of primary sources of information, semi-structured interviews with farms managers and direct observation in the farms of this study. Some secondary sources were also used, such as information collected on specialised and companies' websites. The conduction of semi-structured interviews had as main objectives: to capture the perception the wine cellars/vineyards have about the effect of wine tourism experience on their wine brands, and to realize if their expectations related to wine tourism experiences are confirmed or not.

\section{Analysis}

Based on the information collected, and according the dimensions considered, we prepared in the next section an exploratory analysis which main results are also presented in the Table 3.

\subsection{Dimension A: Experience}

\subsubsection{Atmosphere of the Farm}

A very present conscience about the added value of combining the region's culture and the surrounding landscape with the wine tourism places was found. Paulo
Mesquita (Casa de Sezim) says that "when people arrive here they became delighted, either with the natural landscape, or even with the architecture of the house, the romantic Italian facade". This idea is reinforced by João Soares (Herdade da Malhadinha Nova): "people who come here are looking for the plains, the Alentejo, the vineyards, etc. (...) and at the same time to combine this with the wine, which is the product that most attracts people."

Catarina Pimentel (Quinta da Pacheca), however, alerts to the need of developing this activity on a continuous basis, because the "battle, at the moment, here in the Douro, (...) goes through making tourists stay more than two days. But for this it is necessary to create infrastructures for people have what to do (...) we arrive at the winter and all this offer does not exist".

\subsubsection{Provided Service Interface}

A rather heterogeneous symbiosis in the technology used in the farms was found, whether at website level or at the information management and human component.

According to Isabel Morais (Sogrape), "[wine tourism] emerged as a segment within the tourism itself and became more relevant to the notoriety of the brands. Now has more weight in the company because there is more awareness that the wine tourism is very relevant to the notoriety of the brand. It is a professional business, with great returns in terms of notoriety of the brands." So the correct articulation of all details is essential to achieve the objectives set.

A major concern in adapting the spaces to the needs of the wine tourism demand can be seen, even in cases of greater inertia. For Francisco Guedes (Aveleda), "from the beginning we realised that the future of this house would be (...) this uniqueness of Aveleda, for all that it represents (...). There is a need for constant adaptation (...). Over time the guide couldn't do it all! Always with groups arriving, so it was decided to give a map to the people who wanted it, in such way that they made the visit by their own following the map and ended with a wine tasting ".

As a result of the awareness that these producers have about their weaknesses, the structures have been shown to be mutable and evolutionary in the seeking of improvements and adaptation to the market needs.

However, none of the companies visited performs an automatic processing of the data collected from visitors. In some cases forms to be filled out by visitors about the quality of the service were found, or guest books where tourists are encouraged to leave records and comments, but these data are not treated with the proper tools.

\subsubsection{Service Provided}

The services that visitors will find at their disposal vary depending on the level of development of the company's wine tourism. The services we identify included visits (to the vineyards, gardens, cellars, wine cellars and buildings), simple wine tastings, complex wine tastings, shopping area for wine and other products of the region, grape harvest, 
meals, accommodation and outdoor activities as picnics, radical activities, weddings, concerts, workshops and tailor made experiences.

The interviewees showed very good knowledge of the strengths and the weaknesses of their spaces, as well as of the environment and competition.

\subsubsection{Dissemination Strategies}

The dissemination strategies used by the farms studied are, above all, in function of the target audience they want to achieve. The means used for the dissemination of the companies range from the use of the internet (via own website or operators websites), dissemination actions with journalists of the wine and tourism areas, cooperation with public authorities, participation in national and international specialised fairs (mean recognised as useful for dissemination, in accordance with João Soares because "we can see very well the direct link between our visits to the markets and our presentations and the almost immediate booking, very close over time, of some customers, that because they were with us and have taste our wines so they want to come meet"), agreements with local, national and international tour operators, and more or less informal partnerships, with private entities of the region.

At present, the great function of the wine tourism is to transform the consumers in vehicles of dissemination of the wine brands, in ambassadors of the wine brands. According to João Carvalho (Dão Sul), the main objective of wine tourism is "to make each visitor an ambassador of the brand, and in this way achieve indirect sales in stores, in restaurants, because these people will be able to choose our wines and these people increasingly identify themselves with the brand because, they made a visit".

Table 2. Analysis Results

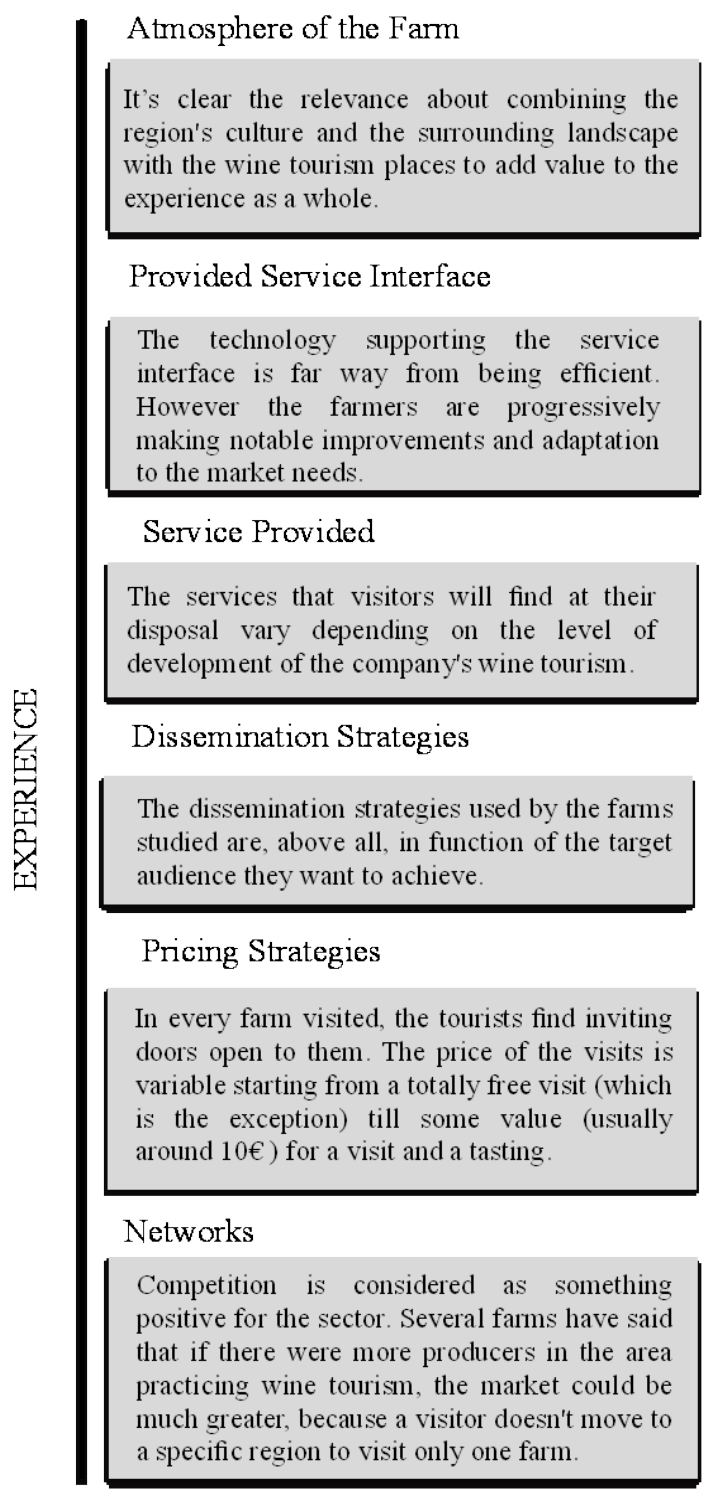

Volume of Sales

All producers have mentioned the existence of a positive and growing relationship between the evolution of the volume of wine sales and the wine tourism practiced.

Extension of the Market

All the interviewees reported that the wine tourism has been growing within the company, both in terms of number of visitors and in terms of their geographical distribution.

\section{Product Diversification}

An evolution and adaptation over time was identified, as a result of the constant changes in the market and with a view to obtaining higher revenue.

Word-of-mouth

It was noted that the word-of-mouth is an effective vehicle for the dissemination of the wine brands for the producers interviewed. 


\subsubsection{Pricing Strategies}

In every farm visited, the tourists find inviting doors open to them. But the price of the visits is variable. According to João Carvalho, in the case of the Quinta do Encontro (belonging to the Dão Sul), the visit "does not require booking, nor is charged any entry", however, generally farms charged a value for the visit. This price helps to create some selection of visitors, as indicated by Catarina Pimentel, the price was set "to achieve a selection of people who came here because unfortunately there were many people who came only to drink", but is also a source of additional revenue.

At the level of pricing strategies self-promotions and partnerships were found. For example, Luís Pato has an informal agreement with the Turismo Centro where people can buy a card at the tourist offices for getting discounts in various areas of the Turismo Centro and also get $10 \%$ discount in the visit to the winery.

The price is always combined with the means of dissemination and promotion, being defined in function of the target audience to reach. In the case of Malhadinha Nova "websites are for niches (...), that fits within our segment, and that only travel on the basis of the recommendations that they received (...). The vast majority of people drink wine because they have to, because they are accustomed to drink wine at meal. This is not my segment, my cheapest wine costs 9 Euros."

\subsubsection{Networks}

Competition is seen by all the respondents as something positive for the sector. According to the producers interviewed, there is a market for new projects and these are needed. The increase in the number of competitors acting in each region would enhance the wine routes, because the diversity of competitors would act as an attraction factor for more consumers. Several farms have said that if there were more producers in the area practicing wine tourism, the market could be much greater, because a visitor doesn't move to a specific region to visit only one farm.

Mentioned by all the producers interviewed was the need for a greater national planning, or at least regional, where the consumer can be able to identify the different wine routes that exist in Portugal, thus fostering the sustainable development of the wine regions. João Carvalho reinforces this notion by stating that "the wine tourism cannot be a product sold because it is only wine or gastronomy.(...) The region will only be seen as a large region of wine tourism if it knows how to sell the wine tourism but also all the others touristic resources".

\subsection{Dimension B - Brand Valorisation}

\subsubsection{Volume of Sales}

All producers have mentioned the existence of a positive and growing relationship between the evolution of the volume of wine sales and the wine tourism practiced. However, none of the respondents has tools that can support this conviction. Still, as mentioned by João Soares "since we started, we have never stopped growing, since the first year that we have recorded growing sales". Catarina Pimentel says that "from March, when we start to get more tourists, shopping in supermarkets immediately increase".

\subsubsection{Extension of the Market}

All the interviewees reported that the wine tourism has been growing within the company, both in terms of number of visitors and in terms of their geographical distribution. João Soares says that they began "with about $80 \%$ of the Portuguese, of course, the project is in Portugal and there was much press talking about it. Over these four years this has evolved and we are now with 50/50, of Portuguese and foreign people. Paul Marsh also identifies that "the trend, from the last year to this year, is to have a very large increase in the requests for wine tastings". This internationalisation of visitors is attached to an internalization of wine sales as tourist usually asks for places at their country to buy the wine they taste in the cellar.

\subsubsection{Product Diversification}

An evolution and adaptation over time was identified, as a result of the constant changes in the market and with a view to obtaining higher revenue. Catarina Pimentel says that, "this started out by fun (...) until we get to this point of having a business running, and working a lot with wine tourism, which greatly help everything else."

The interviews stated that the success of the wine tourism projects is the reason why the producers are seeking to improve the offer that they provide to visitors, with a constant search for new products to stimulate their target audience. For example, according to João Soares: "as the project matures and is evolving, we noticed more and more people coming here."

Isabel Morais reinforces this idea saying that the wine tourism "now has more weight in the company because there is more awareness that the wine tourism is very relevant to the notoriety of the brand".

\subsubsection{Word-of-mouth}

It was noted that the word-of-mouth is an effective vehicle for the dissemination of the wine brands for the producers interviewed. According to Paulo Mesquita, "the passage of word-of-mouth information is very good for us". Also João Soares believes that "the success of Malhadinha and its wine brands is because they have many ambassadors (...) of all social strata, from the most modest to the highest public figures". In the case of Dão Sul, João Carvalho distinguishes the Quinta de Cabriz, whose wine has already "a very strong name in the world of wines, visitors arrive because of the wine; but in the new projects such as the Quinta do Encontro which opened in 2008 and the Paço de Santar, which also opened in 2008, there is no doubt that the vehicle has been the word-of-mouth. People come here to visit us and then recommend us to others". 


\subsection{Relationship between Dimensions}

The opinions collected among producers indicate that they believe wine tourism is a fundamental element for the dissemination of the wine brands, as a way of taking advantage of the farms landscapes and even as a mean of broadening its core business. The producers also have said that wine tourism is a way to leverage the wine brand, despite not having technical tools that will allow them to measure this effect.

It is still referred too, by almost all producers, that wine tourism comes in a natural way, to meet the needs of the demand. The wine tourism, according to the respondents, increases the wine brand recognition and leads to an increase in wine consumption. Despite the lack of control mechanisms to allow them to assess the existence of a positive correlation between the experiences that they provide and the valorisation of the wine brand, everyone referred that this relationship exists.

\section{Conclusions}

Since the objective was to analyze the leverage of wine brands by positive touristic experiences associated with the wine from the perspective of the producers, the investigation was developed by the supply side. The results obtained made it possible to produce the following conclusions with respect to the research issues initially proposed.

The idea that providing positive touristic experiences associated with the wine product allows the leverage of the wine brands of this product was reinforced. The correct perception of the wine producers on the determinants that affect and influence the wine consumer attitude is a key factor for the development of the wine tourism.

The relevance of wine tourism for the future of the wine brands is although variable according the different producers. Nevertheless some of the farms visited, are aware of the advantages of the wine tourism, they, not identify the need for further expansion of this business area, opting to develop the wine tourism as a marginal activity to the business of the company. This happens either by inertia or for being in possession of strong and well-known wine brands. However, other farms develop wine tourism in parallel to the activity of production and marketing of wine, because they identify this area as crucial to the future growth of the company and even for the region in which they are settled.

It must be noted that the correct management of the consumer experience cannot, and should not be static in time. As wine tourism projects are developing, managers shall perform the analysis of its evolution. It was found that with the course of time, the returns obtained from consumers are acting as a stimulus for improving experiences and for the search for new experiences, even in farms where the wine tourism is not so developed. This leads to the conclusion that the model presented in section 3 is a dynamic model, as suggested by Grönroos, [16]. In other words, if the experience fosters the valorisation of the wine brand, this valorisation allows a positive return to the company, encouraging it to generate more experiences related with the wine product, thus creating an upward or positive continuous cycle (Figure 3).

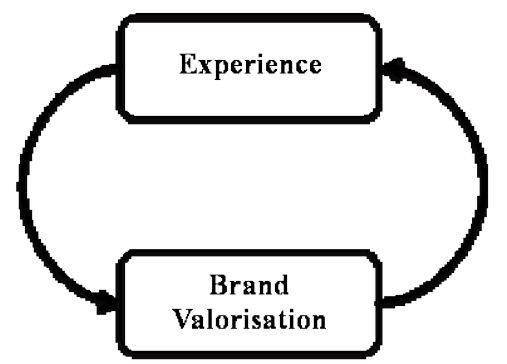

Figure 3. Experience vs Brand Valorisation

What a wine producer with wine tourism offer must ask is if he is using all the resources properly and investing in the right experiential elements, in a long-term perspective. It would be necessary that the wine producers implement a management model that allow them to assess over time the perceived experience of the consumer and the development of strategic mechanisms to adjust and optimize the management of the experience.

Something very evident in this research is the need of the wine and tourism industries join efforts on a common goal, which is to provide unique experiences for the consumer. This joint effort, in conjunction with the development of the competition is fundamental for the creation of a market that attracts a critical mass of consumers, thus enabling the sustainable development of the whole region.

Being the results of this work valid only in an exploratory perspective and in the context of the wine cellars/farms investigated, there is a need for further research that encompasses a broader sample, using a quantitative method, and with the exploration of different countries that are engaged in the practice of wine tourism. It is evident the need to produce more knowledge regarding the supply side of the wine tourism experiences and the effect of them on all the other business variables.

It is still necessary a greater understanding of how the different types of wine experiences contribute to reinforce the wine brand. Similarly it is also important to find an effective way to measure the effect of wine tourism in wine brands valorisation.

\section{REFERENCES}

[1] Alnat, K, and Bruwer, J. (2010), Winery visitations sets: Intra-regional spatial movement of wine tourists in branded wine regions. International Journal of Wine Business Research, Vol 22, N. ${ }^{\circ} 2$, pp. $191-210$.

[2] Asero, V. and S. Patti (2009), "From Wine Production to Wine Tourism Experience: the Case of Italy", American Association of Wine Economists, N. ${ }^{\circ} 52$. 
[3] Bramwell, B. and B. Lane (editors), (2000), Tourism, collaboration \& partnerships: Politics, practice and sustainability, Clevedon, UK: Channel View Publications.

[4] Brand, C. (1997), "Strong creative strategies reinforce the brand promise", Direct Marketing, Vol. 60, N. ${ }^{\circ}$ 8, pp. $46-$ 49.

[5] Brown, G. and D. Getz (2005), "Linking wine preferences to the choice of wine tourism destinations", Journal of Travel Research, Vol. 43, N. ${ }^{\circ} 3$, pp. $266-276$.

[6] Bruwer, J. and K. Alant (2009), "The hedonic nature of wine tourism consumption: an experiential view", International Journal of Wine Business Research,Vol. 21 No 3, pp. 235 257.

[7] Charters, S. and J. Ali-Knight. (2002), "Who is the wine tourist?", Tourism Management, Vol. 23, No 3, pp. 311 319.

[8] Correia, Ricardo and Brito Carlos (2012), "Mutual Influence Between Firms and Tourism Destination: a Case in the Douro Valley", Journal of Tourism and Development N. ${ }^{\circ}$ $17 / 18$, pp. $1711-1726$.

[9] Costa, A. and E. Kastenholz (2010), “O Enoturismo na Rota do Vinho do Porto", $16 .^{\circ}$ Congresso da APDR, Universidade da Madeira, Funchal, 8 a 10 de Junho, Madeira, pp. 1714 1727.

[10] Dodd, T. H. and A. W. Gustafson (1997), "Product, environmental, and service attributes that influence consumer attitudes and purchases at wineries"', Journal of Food Products Marketing, Vol. 4, N. ${ }^{\circ} 3$, pp. $41-59$.

[11] Getz, D., R. Dowling, J. Carlsen and D. Anderson (1999), "Critical success factors for wine tourism", International Journal of Wine Marketing, Vol. 11, N. ${ }^{\circ}$ 3, pp. 20 - 43.

[12] Glaser, B. G. and A. L. Strauss (1967), The Discovery of Grounded Theory: Strategies for Qualitative Research, Chicago: Aldine Pub. Co.

[13] Gómez, M. and A. Molida (2011), "Wine Tourism in Spain: Denomination of Origin Effects on Brand Equity", International Journal of Tourism Research DOI: $10.1002 /$ jtr.

[14] Grängsjö, Y. (2003), "Destination Networking Co-opetition in Peripheral Surroundings", International Journal of Physical Distribution \& Logistics Management, Vol. 33, N. ${ }^{\circ}$ 5 , pp. $427-448$.

[15] Grewal, D., M. Levy and V. Kumar (2009), "Customer experience management in retailing: an organization framework", Journal of retailing, Vol. 85, N. ${ }^{\circ} 1$, pp. $1-14$.

[16] Grönroos, C. (2007), Service Management and Marketing: Customer Management in Service Competition, (3a ed.), John Wiley \& Sons, Chichester.

[17] Hall, C. M., L. Sharples, B. Cambourne and N. Macionis (2000), Wine Tourism around the World: Development, Management and Markets, Oxford: Elsevier ButterworthHeinemann.
[18] Jamal, T. B. and D. Getz (1995), "Collaboration Theory and community tourism planning", Annals of Tourism Research, Vol. 22, N. ${ }^{\circ}$ 1, pp. $186-204$.

[19] Kapferer, J-N. (1992), Strategic Brand Management: New Approaches to Measuring and Managing Brand Equity, London: Kogan Page.

[20] Kapferer, J-N. (2004), The New Strategic Brand Management, London: Kogan Page.

[21] Mazo-Navarro, M. and Pedrajo-Iglesias, M. (2009), "Profile of a wine tourist and correspondence between destination and preferred wine: A study in Aragon, Spain", Journal of Travel \& Tourism Marketing, Vol. 26, pp. 670-687.

[22] Nowak, L.I. and S. K. Newton (2006), "Using the tasting room experience to create loyal customers", International Journal of Wine Marketing, Vol. 18, N. ${ }^{\circ} 3$, pp. $157-65$.

[23] Pine, J. B. and H. J. Gilmore (1999), The Experience Economy: Work is Theatre and Every Business a Stage, Boston: Harvard Business School Press.

[24] Presenza, A., A. Minguzzi and C. Petrillo (2010), "Managing Wine Tourism in Italy", Journal of Tourism Consumption and Practice, Vol. 2, N. ${ }^{\circ}$ 1, pp. $46-61$.

[25] Ritchie, J. R. B., V. W. S. Tung and R. J. B. Ritchie (2010) "Tourism Experience Management Research: Emergence, Evolution and Future Directions", International Journal of Contemporary Hospitality Management, Vol. 23, N. ${ }^{\circ} 4$, pp. $419-438$

[26] Safavi, F. (1996), "Winning the battle of corporate/brand images: An image-focused model for selection of names and logos", The Journal of Brand Management, Vol. 3, N. ${ }^{\circ}$ 6, pp. $377-399$.

[27] Schmitt, B. H. (1999), Experiential Marketing - How to Get Customers to Sense, Feel, Think, Act and Relate to Your Company and Brands, New York, NY: The Free Press, A Division of Simon and Schuter Inc.

[28] Strauss, A. L. and J. M. Corbin (1990), Basics of qualitative research: Grounded theory procedures and techniques, Newbury Park: Sage.

[29] Van Mesdag, M. (1997), "Brand strategy needs turning back to front", Marketing Intellegence \& Planning, Vol. 15, N. ${ }^{\circ} 3$, pp. $157-159$.

[30] Verhoef, C. P., N. K. Lemon, A. Parasuman, A. Roggeveen, M. Tsiros and A. S. Leonard, (2009), "Customer Experience Creation: Determinants, Dynamics and Management Strategies", Journal of Retailing, Vol. 85, N. ${ }^{\circ} 1$, pp. $31-41$

[31] Williams, P. (2001a), "Positioning wine tourism destinations: an image analysis', International Journal of Wine Marketing, Vol. 13 N. ${ }^{\circ}$ 3, pp. 42 - 59.

[32] Williams, P. (2001b), "The evolving images of wine tourism destinations", Tourism Recreation Research, Vol. 26 N. ${ }^{\circ} 2$, pp. $3-10$.

[33] Zeithaml V and Bitner MJ (2003), Services Marketing, 3rd edt. McGraw-Hill: New York. 